KEYWORDS

Fuels

Taxation

Gasoline

Diesel fuels

Automobiles

Supply and demand

Chile
CEPAL REVIEW 102 - DECEMBER 2010

\section{Differential fuel taxes and their effects on automobile demand}

\author{
Claudio A. Agostini
}

$\mathrm{F}$

uel taxation policy in Chile has always been to keep taxes on diesel lower than those on gasoline. The proportion of automobiles with diesel engines has grown considerably as a result. Just $20 \%$ of diesel engine emissions are equivalent to $80 \%$ of gasoline engine emissions, and this affects the level of externalities associated with automobile use, especially in cities such as Santiago where pollution levels are high. This study estimates the effect of the fuel tax differential on automobile demand. The findings indicate diesel automobile demand elasticities of -3.4 and 2.1 with respect to the price of the vehicle and the tax differential. The scale of these effects means there is scope for substantial emissions cuts by way of tax changes to equalize gasoline and diesel tax rates and create a specific tax on diesel automobiles.
Claudio A. Agostini Associate Professor, ILADES-Alberto Hurtado University • agostini@uahurtado.cl 


\section{I}

\section{Introduction}

In Chile, the government has greatly increased the specific tax on gasoline over the past 20 years while keeping the specific tax on diesel unchanged. The basic motive has simply been to increase or recoup tax revenues; because demand for fuel is assumed to be fairly inelastic, the thinking is that the distortions caused by taxation should be minimized by applying it in these markets. Proportionally equivalent increases in all fuel markets would be the natural outcome of this logic, but gasoline taxes have risen by proportionally more than the tax on diesel, thus changing the relative prices of the two. In 1990, the gasoline tax was increased from 3 UTM per cubic metre to 3.6186 UTM. $^{1}$ It was then raised to 4.4084 UTM in 1995, 5.2 UTM in 2000 and 6 UTM in 2001. In 2008 it was cut first to 4.5 UTM in March and then to 3.5 UTM in September. Throughout, the tax on diesel has been held at 1.5 UTM per cubic metre.

This relative price change deriving from tax policy in fuel markets has had two effects. The first has been an increase in the consumption of diesel relative to gasoline in all uses for which the two fuels are substitutes. The second has been an incentive to purchase diesel rather than gasoline cars. Imports of diesel-powered light passenger vehicles rose from 13,646 units in 1997 to 61,433 in 2007. Similarly, the total fleet of diesel automobiles rose from 267,341 units in 2002 to 566,122 in 2008 , i.e., there was an increase of $112 \%$ in six years, while the fleet of gasoline automobiles grew by $30 \%$ in the same period. The diesel and gasoline automobile fleets thus grew by $13.3 \%$ and $4.5 \%$ a year between 2002 and 2008, respectively. The result, as figure 1 shows, is that the share of diesel automobiles in the total has grown steadily over recent years, rising from $12.7 \%$ in 2002 to $19.2 \%$ in 2008 in the country as a whole, and from $9.1 \%$ to $14.4 \%$ in the Metropolitan Region over the same period.

This change in the composition of the automobile fleet is important because of the externalities automobile use produces. There are externalities

1 The monthly tax unit (UTM) is an index used to maintain the value of taxes in constant money. In June 2010, one UTM was worth 37,083 Chilean pesos. such as road congestion and traffic accidents that are unconnected with the type of engine in the automobile, so that different tax treatment for different fuel types ought not to affect their level directly. ${ }^{2}$ However, there are externalities such as air pollution from emissions that are related to the type of engine.

Given that pollution from an automobile creates an external cost for society which automobile owners and users do not take into account in their decisionmaking, tax policy can play an important part in internalizing this cost. Three decisions are relevant here. The first is the number of kilometres driven since it is this, in combination with the automobile's emissions per kilometre travelled, that determines the total volume of pollution produced. The second is the type of fuel used by the automobile and the emissions associated with it. The third is the choice of vehicle characteristics that directly or indirectly affect emissions per kilometre travelled, such as the age of the car, its fuel efficiency (kilometres per litre), engine size, etc.

An optimal tax policy would be one that led to consumers incorporating external costs into their demand for automobiles, including fuel type. If a vehicle's emissions are proportional to its fuel consumption and do not depend on its design and engine type, as is the case with carbon dioxide emissions from automobiles, fuel use alone will determine the level of emissions and a tax per litre will allow consumers to internalize the social costs of their emissions. Thus, a gasoline tax encourages consumers to purchase smaller or more fuel-efficient vehicles, maintain them better and change their usage patterns (fewer kilometres travelled) to lower consumption (Portney and others, 2003; West and Williams, 2004; Bento and others, 2005). Furthermore, given that gasoline and leisure are relative complements, increasing the gasoline tax will increase the supply of labour, generating additional

\footnotetext{
2 Tax rates obviously have a direct effect on levels of externalities, and potentially a considerable one. Thus, in the case of the United States, it has been estimated that an increase of US\$ 1 per gallon ( 3.7854 litres) would cut gasoline consumption by between $15 \%$ and $20 \%$, mileage by between $11 \%$ and $12 \%$ and road accident deaths by between $16 \%$ and $18 \%$, while an extra US\$ 100 billion in taxes would be raised over 10 years (Haughton and Sarkar, 1996).
} 
FIGURE 1

Chile: proportion of diesel-powered automobiles

(Percentages)

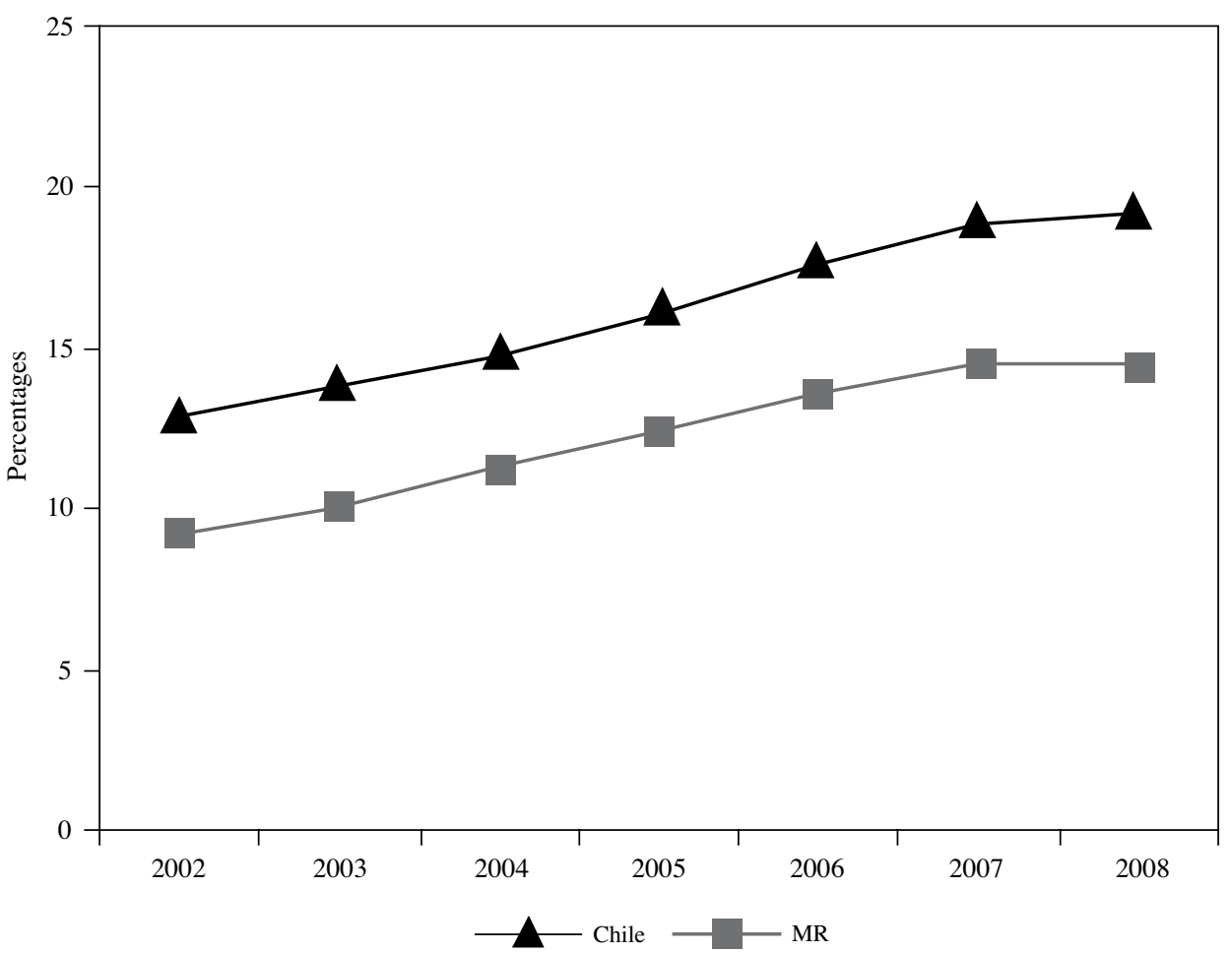

Source: “Anuarios parque de vehículos en circulación”, National Institute of Statistics (INE) [online] http://www.ine.cl/canales/chile_ estadistico/estadisticas_economicas/transporte_y_comunicaciones/parquevehiculos.php.

MR: Metropolitan Region.

efficiency gains (West and Williams, 2004). Conversely, increasing fuel economy standards encourages greater automobile use by reducing the cost per kilometre travelled (Thorpe, 1997).

Nitrogen oxide and carbon monoxide emissions, on the other hand, are not proportional to fuel use but depend directly on a vehicle's engine size and type. A catalytic diesel automobile emits between 0.6 and 0.8 grams of nitrogen oxide $\left(\mathrm{NO}_{\mathrm{x}}\right)$ and between 0.04 and 0.09 grams of particulate matter per kilometre, while a gasoline car with a catalytic converter emits about 0.1 grams of nitrogen oxide per kilometre and no particulate matter. What this works out at is that, on average, $20 \%$ of diesel automobile emissions are equivalent to $80 \%$ of gasoline automobile emissions, making the pollution externalities of the two types of vehicle very different.

Given the environmental situation in some Chilean cities, the externalities generated by diesel vehicles are greater than those of gasoline vehicles, which means that the difference in specific taxes favouring diesel is not consistent with a Pigovian tax approach designed to correct externalities. Broadly speaking, then, a tax treatment that favours diesel does not seem justifiable on environmental grounds (see, for example, Michaelis, 1995). In particular, emissions from diesel engines have major environmental disadvantages from the standpoint of urban air quality (Crawford and Smith, 1995). Even under the more demanding new standards for particulate matter established in Europe, there is evidence of negative effects on climate change (Jacobson, 2002) and on urban mortality (Mazzi and Dowlatabadi, 2007).

Other elements of taxation policy undoubtedly need to be considered for optimum gasoline taxes to be determined, particularly the role of diesel as a production input in some industries, but it is important to determine the effect of the current tax differential 
on the composition of the automobile fleet in Chile in order to be able to identify its repercussions on certain cities with high levels of environmental pollution, such as Santiago and Temuco. For this, the important question is how sensitive diesel automobile sales are to the relative specific taxes and vehicle prices. These two elements are complementary from the standpoint of optimal tax policy, since besides the fuel tax it is possible to use a tax on diesel automobiles to correct externalities. The reason is that diesel automobiles, while more expensive, use less fuel per kilometre, and willingness to pay for this characteristic varies by consumer type, depending on how the automobile is to be used (distance driven per year). A tax on diesel automobiles makes it possible to discriminate by consumer type, raising prices by more for consumers who generate greater externalities owing to their more intensive vehicle use. ${ }^{3}$

The objective of this study is to estimate the elasticities of automobile demand by engine type in relation to price and specific fuel taxes. This is a first input of relevance for evaluating the effects of current tax policy on fuels in Chile and proposing tax changes to internalize external costs associated with automobile use, particularly as regards air pollution.

The remainder of the article continues as follows. Section II presents an automobile demand model together with methodological considerations for estimating it. Section III describes the data used in the empirical analysis. Section IV presents the findings of the estimation and section $\mathrm{V}$ concludes with some future research and policy recommendations.

\section{II}

\section{An automobile demand model}

Demand functions are generally estimated using uniform prices for an industry's products, and a single estimate for the price elasticity of demand is obtained as a result. Such estimates are valid for homogeneous products, but they omit information that is important for an understanding of consumers' substitution patterns in the case of differentiated or heterogeneous products. The reason is that differences between products translate into different demand elasticities, making it important when estimating them to take explicit account of the characteristics differentiating products from one another. This is true of automobile demand, since a consumer can choose between different vehicle makes and models. When deciding which automobile to buy, consumers compare different characteristics across the different makes and models available. Price is undoubtedly among the most important characteristics, but consumers will also consider the type of engine (gasoline or diesel), as this is a major determinant of the automobile's annual running costs. Because consumers have to choose between different makes and models with engines of differing types and sizes, demand for automobiles is a demand for differentiated products.
It is also important to realize that consumers have the option of not buying an automobile (outside option). It is important for this option to be considered in the estimation of demand, because if it did not exist then it would be possible to raise the prices of all automobiles uniformly without demand being affected, as relative prices would remain constant.

Estimating demand for differentiated products is complicated, chiefly because of the large number of parameters that have to be estimated. Where $\mathrm{N}$ different products are involved, $\mathrm{N}$ price elasticities and $\mathrm{N}(\mathrm{N}-1)$ cross-price elasticities need to be estimated. This means that for most cases the econometric model is "overparameterized" and impossible to estimate. There are two ways of solving this problem. The first is to aggregate similar products until there are just a few product groups. The largest cost of this strategy is that some parameters which might be of interest are lost.

\footnotetext{
3 There is evidence that this type of price discrimination by engine type is employed by vehicle manufacturers (Verboven, 2002). Between $75 \%$ and $90 \%$ of the price differential between diesel and gasoline automobiles appears to be due to price discrimination between heavy and light vehicle users.
} 
The second way is to model product choice explicitly. This approach is based on the work of McFadden (1974), who developed discrete choice models to characterize the choice of products by a consumer, and it is the one used in the present study. ${ }^{4}$

A second difficulty in estimating demand for differentiated products is the heterogeneity of consumers. If consumers did not have different preferences they would all buy the same automobile, conditional upon income. This does not happen, though, because consumers have individual characteristics which lead them to prefer one model or make of automobile out of all those available, and these characteristics somehow need to be incorporated into the demand model.

\section{Discrete choice}

By contrast with a standard consumption model, where the quantity consumed is a continuous variable, what is analysed in a discrete choice model is a situation where the relevant consumption decision is discrete. In the case of the decision to buy an automobile, for instance, the relevant thing is what automobile a consumer buys, rather than how many. To be able to estimate demand for goods or services that are consumed discretely, a discrete choice model relates each consumer's choice statistically with his or her personal characteristics and the characteristics of the different products or services available to be chosen. In this way, the model can be used to estimate the likelihood of a consumer picking a specific alternative. ${ }^{5}$

To estimate models of this type it is necessary to specify, first, the indirect utility function of a consumer $i$ purchasing an automobile with an engine of type $m$ (cylinder capacity and gasoline or diesel) in year $t$. Following Berry (1994) and Nevo (2000), this is defined as:

$$
U_{i m t}^{*}\left(X_{m t}, P_{m t}, \xi_{m t}, \tau_{t}, v_{i} ; \theta\right)
$$

\footnotetext{
${ }^{4}$ Using this approach, Berry, Levinsohn and Pakes (1995 and 1998) study strategic price interactions between automobile manufacturers in the United States; Nevo (2001) estimates demand for cereals in the United States; and Agostini (2007) and Agostini and Jalile (2009) estimate the effect of taxes on foreign investment in the United States and Latin America, respectively.

${ }^{5}$ While the estimation may be carried out with data on individual consumer decisions, this is not a requirement for using these models and it can be done with aggregated market-level data for each alternative.
}

where $X$ is a vector of size $k$ of an automobile's observable characteristics, $\xi$ are an automobile's unobservable characteristics, $\tau$ is the specific tax on the fuel used by the automobile, $P$ is the automobile's price, $v$ are consumers' individual characteristics and $\theta$ are the unknown parameters to be estimated.

A simple functional form used in the literature for the utility function (1) is: ${ }^{6}$

$$
U_{i m t}^{*}=\alpha P_{m t}+\gamma \tau_{t}+X_{m t} \beta+\xi_{m t}+v_{i m t}
$$

The functional form used in (2) assumes that the unobserved heterogeneity of consumers (the individual characteristics that determine their preferences) is captured by a random shock vimt. ${ }^{7}$ The choice of a specific functional form along with the assumptions made about the distribution of $\mathrm{v}$ have a considerable effect on patterns of substitution between products (Berry, 1994).

As noted earlier, it is important for the analysis to consider the possibility that the consumer may decide not to purchase an automobile (possibly deciding to purchase a motorcycle, use only public transport, etc.). The utility function of this outside alternative is defined as:

$$
U_{i o t}^{*}\left(X_{o t}, \xi_{o t}, \tau_{o t}, v_{i}, \theta\right)
$$

and the specific functional form taken for this is:

$$
\pi_{i o t}^{*}=\xi_{o t}+v_{i o t}
$$

The assumption implicit in this model is that consumers purchase just one automobile, namely the one that gives them the highest level of utility. Thus, consumer $i$ will choose to purchase an automobile of engine type $m$ if and only if that purchase provides him or her with the greatest utility of all the alternatives. In other words, if the following condition is met:

\footnotetext{
${ }^{6}$ See Berry (1994), Berry, Levinsohn and Pakes (1995) and Nevo (2000). The model is fairly general, however, and can be used with different specifications subject to minor adjustments.

7 A consumer is thus defined as a vector of specific shocks by automobile engine type: $\left(v_{i o t}, v_{i 1 t}, \ldots, v_{i M t}\right)$.
} 


$$
\begin{aligned}
& \alpha P_{m t}+\gamma \tau_{t}+X_{m t} \beta+\xi_{m t}+v_{i m t} \geq \alpha P_{k t}+ \\
& \gamma \tau_{t}+X_{k t} \beta+\xi_{k t}+v_{i k t}
\end{aligned}
$$

for any $\mathrm{k} \geq 0$ and $\mathrm{k} \neq \mathrm{m}(k=0$ represents the outside option: an alternative that entails not buying an automobile).

Condition (5) implicitly defines a set of unobserved individual characteristics $v_{\text {imt }}$ leading to the choice of automobile model/make $m$. This set is defined by:

$$
A_{m t}\left(\delta_{. t}\right)=\left\{v_{i . t} \mid \delta_{m t}+v_{i m t} \geq \delta_{k t}+v_{i k t} \forall k=0 \ldots M\right\}
$$

where $\delta_{. t}=\alpha P_{. t}+\gamma \tau_{t}+X_{. t} \beta+\xi_{. t}$ is the mean utility of each make/model.

In the case of the outside option, the mean utility $\left(\delta_{\text {ot }}\right)$ cannot be identified without making more assumptions or normalizing one of the makes of automobile. The simplest way of identifying it, and the standard alternative used in the literature, is to normalize $\xi_{\text {ot }}$ at zero.

It is then possible, for a given set of parameters, to predict the market share of each engine type as a function of the characteristics of the automobile, its price, taxes and unknown parameters. The market share of model $/$ make $m$ in period $t, \mathrm{~S}_{\mathrm{mt}}$, is determined by the proportion of consumers for whom condition (5) is met, i.e., for whom consuming model $m$ provides greater utility than any of the other alternatives, including the outside one. This proportion is determined by the likelihood of $v_{i t}$ being in set $A_{m t}$. Given a distribution function and a density for $v, F(v)$ and $f(v)$, respectively, the market share of model $m$ in period $t$ is:

$$
s_{m t}\left(\delta_{. t}\right)=\int_{A_{m t}} f(v) d v
$$

In order to calculate the integral of equation (7), it is necessary to assume a distribution for vimt. An assumption traditionally used in the literature is that vimt are independent and equally distributed in accordance with an Extreme Value Type I distribution function. ${ }^{8}$ In this case, the market share of engine type $m$ is:

\footnotetext{
${ }^{8}$ See, for example, McFadden (1974), Cardell and Dumbar (1980), Boyd and Mellman (1980) and Tardiff (1980).
}

$$
s_{m t}=\frac{\exp \left(\alpha P_{m t}+\gamma \tau_{m t}+X_{m t} \beta+\xi_{m t}\right)}{1+\sum_{k=1}^{M} \exp \left(\alpha P_{m t}+\gamma \tau_{k t}+X_{k t} \beta+\xi_{k t}\right)}
$$

The estimation strategy consists in choosing the parameters that minimize the distance between the market shares predicted by the model and those observed, which means solving the following implicit equation system: ${ }^{9}$

$$
s_{. t}\left(X_{. t}, P_{. t}, \tau_{. t}, \delta_{. t} ; \theta\right)=S_{. t}
$$

where $s_{. t}(\bullet)$ are the market shares defined by equation (7) and $S_{. t}$ are the observed market shares.

Equation (9) can now be resolved analytically to get:

$$
\delta_{m t}=\ln \left(S_{m t}\right)-\ln \left(S_{o t}\right)
$$

where $S_{m t}$ and $S_{o t}$ are the market shares of engine type $m$ and the outside option, respectively.

Thus, the aggregate demand equation to be estimated is:

$$
\ln \left(S_{m t}\right)-\ln \left(S_{o t}\right)=\alpha P_{m t}+\gamma \tau_{m t}+X_{m t} \beta+\xi_{m t}
$$

The price elasticities of the market shares, as defined by equation (8), are:

$$
\eta_{m t}^{P}=\frac{\partial s_{m t}}{\partial P_{k t}} \frac{P_{k t}}{s_{m t}}= \begin{cases}\alpha P_{m t}\left(1-s_{m t}\right) & \text { if } m=k \\ \alpha P_{k t} s_{k t} & \text { if } m \neq k\end{cases}
$$

Similarly, the tax rate elasticity of the market shares is:

$$
\eta_{m t}^{\tau}=\frac{\partial s_{m t}}{\partial \tau_{m t}} \frac{\tau_{m t}}{s_{m t}}= \begin{cases}\gamma \tau_{m t}\left(1-s_{m t}\right) & \text { if } m=k \\ \gamma \tau_{k t} s_{k t} & \text { if } m \neq k\end{cases}
$$

In summary, this model can be used to solve the problem of "overparameterization" of demand

\footnotetext{
${ }^{9}$ The integral of equation (7) can be calculated analytically using assumptions about the distribution of $v$.
} 
for differentiated products and makes it possible to obtain consistent estimators of the elasticities concerned. ${ }^{10}$ Lastly, it is important to consider that

10 This model has been used in the literature by studies dealing with automobile and fuel markets. For example, Agras and Chapman (1999) estimate the impact of emissions standards and fuel taxation on total greenhouse gas emissions in the United the price variable might be endogenous (with $P_{m t}, \xi_{m t}$ ), in which case it is necessary to estimate equation (11) using instrumental variables.

States transport sector; Levinsohn (1996) estimates the effect of different trade policies on automobile sales; and Greene (1986) analyses the evolving market share of diesel automobiles in the United States.

\section{III}

\section{Data used in the empirical analysis}

The empirical analysis uses monthly data on automobile imports registered by the National Customs Service for the period from 2002 to 2008 . The breakdown for each entry identifies the type of engine (gasoline or diesel), cylinder capacity in four categories (under $1,000 \mathrm{~cm}^{3}$, between $1,000 \mathrm{~cm}^{3}$ and $1,500 \mathrm{~cm}^{3}$, between $1,500 \mathrm{~cm}^{3}$ and $3,000 \mathrm{~cm}^{3}$, and over $3,000 \mathrm{~cm}^{3}$ ), whether the automobile is an off-road or four-wheel drive $(4 \times 4)$ vehicle, and the country of origin. For each of these groups of automobiles, the customs register lists the number of units imported, the country of origin, the average unit price and the standard deviation of the average price. ${ }^{11}$ Unfortunately, no breakdown of data by unit is available, nor was it possible to obtain a classification by model or even by make of automobile.

Table 1 gives a statistical summary of the data. The Quantity variable is the number of vehicles imported per month in each of the 304 categories. ${ }^{12}$ It provides the basis for calculating the logarithm of the monthly share of vehicle imports in each category, which is used as a dependent variable in the regression $\left(\log S_{m j t}\right)$. Although no data are available to calculate the proportion of consumers who prefer the option of not having a car each month, there are data on

\footnotetext{
11 There are records of imports from 45 countries, but 18 countries account for over $95 \%$ of all vehicles imported. For this reason, the empirical analysis specifies the proportion of automobiles imported from each of these 18 and groups the rest into an "Other" category.

12 The 304 categories of automobile in the data arise from the interaction of: 4 engine sizes, 2 engine types, 2 vehicle types (automobile and off-roader or 4x4) and 19 countries of origin.
}

motorcycle imports, making it possible to calculate the market share of this outside option $\left(\log S_{o t}\right)$, which is accordingly used in the empirical analysis.

The price variable is the average dollar unit price of automobiles in each category. The variables generated by the tariff categories of the different automobile import entries were used to determine seven dummy variables capturing these characteristics: Engine 1,000 for engine sizes under $1,000 \mathrm{~cm}^{3}$, Engine 1,500 for engine sizes between $1,000 \mathrm{~cm}^{3}$ and $1,500 \mathrm{~cm}^{3}$, Engine 3,000 for engine sizes between $1,500 \mathrm{~cm}^{3}$ and $3,000 \mathrm{~cm}^{3}$, Engine 3,000+ for engine sizes over $3,000 \mathrm{~cm}^{3}, 4 \mathrm{x} 4$ for off-road or four-wheel drive vehicles, Diesel for diesel-engined vehicles and, lastly, Free Zone for all vehicles entering by one of the three free zones that exist in Chile (Arica, Iquique and Punta Arenas). The Tax variable is the monthly value, in dollars per litre, of the specific tax on gasoline. The IMACEC variable measures the monthly change in economic activity in the country, being based on the performance of $90 \%$ of the goods and services that make up gross domestic product (GDP); the monthly indicator of economic activity (IMACEC) is published by the Central Bank of Chile. Lastly, the Steel Price variable is the price of the type of stainless steel used by automobile producers, as published in the MEPS Stainless Steel Review on the basis of information from contracts between steel producers and consumers. Because steel is a production input in automobile manufacturing that ought not to be correlated with unobserved variables determining the demand for automobiles, its price is used as an instrumental variable for the price of automobiles when estimating demand. 
TABLE 1

Statistical summary

\begin{tabular}{lcccc}
\hline & Average & Standard deviation & Minimum & Maximum \\
\hline Quantity & 151.22 & 343.63 & 1 & 3544 \\
$\mathrm{~S}_{\text {mjt }}$ & 0.0101 & 0.0218 & 0.004 & 0.197 \\
Price & 12379 & 663.8 & 2000 & 152352 \\
Engine 1,000 & 0.034 & 0.165 & 0 & 1 \\
Engine 1,500 & 0.099 & 0.278 & 0 & 1 \\
Engine 3,000 & 0.214 & 0.376 & 0 & 1 \\
Engine 3,000+ & 0.131 & 0.295 & 0 & 1 \\
4x4 & 0.087 & 0.126 & 0 & 1 \\
Free Zone & 0.203 & 0.327 & 0 & 1 \\
Diesel & 0.248 & 0.291 & 0.143 & 1 \\
Tax & 0.254 & 0.064 & -1.8 & 0.411 \\
IMACEC & 0.305 & 0.821 & 2091 & 1.7 \\
Steel Price & 341.25 & 1328.71 & 732 \\
\hline
\end{tabular}

Source: National Customs Department, Central Bank of Chile and MEPS Stainless Steel Review.

Note: Average unit prices in dollars.

Engine sizes are stated in $\mathrm{cm}^{3}$.

IMACEC: Monthly indicator of economic activity.

Free Zone: Arica, Iquique and Punta Arenas.

\section{IV}

\section{Results of the estimation}

Table 2 shows the results of estimating equation (11). Model (1) is the ordinary least squares estimation, and therefore does not take account of the possible endogeneity of automobile prices. In Chile, $100 \%$ of light passenger automobiles are imported, meaning that supply is determined simply by the international price, additionally bearing in mind that Chile is a small country. For this reason, the problem of simultaneity in determining the equilibrium price in the automobile market does not generate problems of identification. It is possible that there may be measurement errors in the price variable, however, as it is an average for each category of automobile. To take this possibility into account and remove a possible endogeneity bias when estimating price elasticity, equation (11) is estimated once again using the price of steel as an instrumental variable for the price of automobiles.

The empirical results are generally quite satisfactory. The regressions are able to explain about $56 \%$ of the variation in the data, the signs of the coefficients are the expected ones for automobile demand and they are all statistically significant at a
$5 \%$ confidence interval. The demand for automobiles is greater for engine sizes larger than the omitted category of engines smaller than $1,000 \mathrm{~cm}^{3}$, but the most considerable effect is seen with engines of between $1,500 \mathrm{~cm}^{3}$ and $3,000 \mathrm{~cm}^{3}$, which is where most demand is concentrated. Similarly, the findings reveal a positive effect on aggregate automobile demand of diesel-powered as compared to gasolinepowered vehicles, and of four-wheel drive vehicles as compared to those with two-wheel drive. Although the size of the effects is fairly small, with elasticities of between 0.2 and 0.4 , this is consistent with the growing market share of both diesel and $4 \times 4$ automobiles over time. The positive repercussions of the Free Zone reflect the opportunity to import automobiles free of customs duties in two regions of the country, increasing demand there relative to the other regions of Chile. On average, everything else being constant, having a free zone increases relative demand for automobiles by $3.6 \%$. The positive effect of the IMACEC on automobile demand is consistent with a positive income elasticity, but also reflects the 
TABLE 2

\section{Estimates of the automobile demand equation}

\begin{tabular}{|c|c|c|}
\hline & (1) & (2) \\
\hline Price & $\begin{array}{l}-0.00028^{*} \\
(0.000091)\end{array}$ & $\begin{array}{l}-0.00028^{*} \\
(0.00012)\end{array}$ \\
\hline Engine 1,500 & $\begin{array}{r}0.0032 * \\
(0.0011)\end{array}$ & $\begin{array}{c}0.0034^{*} \\
(0.0013)\end{array}$ \\
\hline Engine 3,000 & $\begin{array}{c}0.0026^{*} \\
(0.0011)\end{array}$ & $\begin{array}{c}0.0028^{*} \\
(0.0013)\end{array}$ \\
\hline Engine $3,000+$ & $\begin{array}{c}0.0011^{*} \\
(0.0004)\end{array}$ & $\begin{array}{c}0.001^{*} \\
(0.0005)\end{array}$ \\
\hline $4 \times 4$ & $\begin{array}{c}0.0184^{*} \\
(0.0032)\end{array}$ & $\begin{array}{c}0.0193 * \\
(0.0043)\end{array}$ \\
\hline Free Zone & $\begin{array}{r}0.0462^{*} \\
(0.0152)\end{array}$ & $\begin{array}{c}0.0484^{*} \\
(0.0167)\end{array}$ \\
\hline Diesel & $\begin{array}{c}0.002^{*} \\
(0.0002)\end{array}$ & $\begin{array}{c}0.002 * \\
(0.0006)\end{array}$ \\
\hline Tax & $\begin{array}{l}-0.0301 \\
(0.0527)\end{array}$ & $\begin{array}{l}-0.0318 \\
(0.0507)\end{array}$ \\
\hline IMACEC & $\begin{array}{c}0.4011^{*} \\
(0.1785)\end{array}$ & $\begin{array}{c}0.4036^{*} \\
(0.1918)\end{array}$ \\
\hline Constant & $\begin{array}{c}-13.82^{*} \\
(1.56)\end{array}$ & $\begin{array}{l}-9.74^{*} \\
(1.67)\end{array}$ \\
\hline Country of origin dummies & Yes & Yes \\
\hline $\mathrm{R}^{2}$ & 0.557 & 0.563 \\
\hline $\mathrm{F}$ & 141.7 & 152.1 \\
\hline $\mathrm{N}$ & 8307 & 8307 \\
\hline
\end{tabular}

Source: author's estimates based on data detailed in table 1.

* Significant at $5 \%$.

Note: Model (1) estimated by ordinary least squares with robust errors; model (2) estimated by instrumental variables and bootstrapping with 1,000 repetitions for errors.

Engine sizes are stated in $\mathrm{cm}^{3}$.

Free Zone: Arica, Iquique and Punta Arenas. IMACEC: Monthly indicator of economic activity.

$\mathrm{R}^{2}$ : Goodness of fit. F: Fischer test. N: Number of observations.

role played by the economic cycle in vehicle imports. An increase of $1 \%$ in monthly economic activity is associated with an average increase of about $1.4 \%$ in automobile demand.

The coefficients of greatest interest in the findings are those related to price and the fuel tax. Price elasticity for aggregate automobile demand in Chile, as evaluated at the mean of the sample, is -3.4. This value is not very different from the results obtained by other studies in the economic literature. In fact, while somewhat greater than the value of -2.4 estimated by Trandel (1991), it is very close to the -3.28 estimated by Goldberg (1995) and within the range of
-3.0 to -4.5 estimated by Berry, Levinsohn and Pakes (1995). ${ }^{13}$ Price elasticities vary both by engine type and by engine size, reflecting consumers' patterns of substitution between different types of automobiles. Automobiles with engines larger than $3,000 \mathrm{~cm}^{3}$ have the greatest price elasticity $(-3.71$, evaluated at the mean of the sample), while automobiles with engines of between $1,500 \mathrm{~cm}^{3}$ and $3,000 \mathrm{~cm}^{3}$ have the lowest (-2.6, also evaluated at the mean). ${ }^{14}$ This range denotes a greater elasticity of demand between engine sizes than is found in developed countries. For the United States, for example, Bento and others (2009) estimate elasticities ranging from -1.44 for compact cars to -2.3 for minivans. The price elasticity of $4 \times 4$ vehicles, lastly, is estimated at -3.83 , making them the most price-elastic vehicles in Chile.

The fuel tax elasticity of demand for diesel automobiles is estimated at -2.1 , evaluated at the mean of the sample. ${ }^{15}$ Given that the diesel tax has been kept unchanged throughout the period, the effect of the tax differential between gasoline and diesel is identified in this elasticity. The magnitude of this elasticity, while smaller than the price elasticity, is not small from the standpoint of the role played by tax policy. Fuel tax elasticity partly captures the annual cost of using the automobile, with greater use requiring higher gasoline consumption, so that narrowing the tax rate gap between gasoline and diesel and levying a tax on diesel automobiles would considerably reduce the air pollution associated with diesel.

In particular, increasing the diesel tax from its current rate of 1.5 UTM per cubic metre to 4.5 UTM and thereby equalizing it with the gasoline tax would reduce the proportion of diesel automobiles by almost 3 percentage points. In the case of the Metropolitan Region, assuming the current growth in diesel automobiles remained constant, this would imply about 11,300 fewer imports of diesel automobiles in the next five years. Assuming each vehicle covered

13 The first studies conducted showed much lower elasticities, however, with values in the range of -1 to -1.5 (see, for example, Chow, 1957; Suits, 1958; Wykoff, 1973).

14 Elasticities are calculated by the formula set out in (12) using market shares and price for the specific $m$ group. Thus, for example, price elasticity for aggregate demand is calculated as $-0.00028 * 12,379$ $(1-0.0101)=-3.4$. For the different types of automobile, elasticity is calculated in the same way but using the respective average price and market share for each group of automobiles: engine size over $3,000 \mathrm{~cm}^{3}$, engine size between $1,500 \mathrm{~cm}^{3}$ and $3,000 \mathrm{~cm}^{3}$, and $4 x 4$. See Nevo (2000) for details on the derivation and calculation of elasticities.

15 Tax elasticity is calculated by the formula set out in (13). 
12,000 kilometres a year, this would mean 950 tons less nitrogen oxide and 88 tons less particulate matter being emitted annually. If a tax were additionally levied on diesel automobiles at a rate of $1 \%$ of vehicle value,

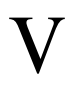

\section{Conclusions}

In Chile, one of the important effects of the current difference in tax rates between gasoline and diesel is that it incentivizes the purchase of diesel automobiles. Thus, the proportion of the automobile fleet with diesel engines in the country rose from about $12 \%$ in 2002 to $19 \%$ in 2008. Since diesel automobiles emit more nitrogen oxide than gasoline automobiles, as well as particulate matter, the externalities associated with air pollution from automobile use have been increasing. This is particularly significant for cities with high levels of pollution in winter, such as Santiago and Temuco. To be able to quantify the scale of this problem and consider tax policy alternatives that would allow externalities to be internalized by the owners of diesel automobiles, it is necessary to know the price and fuel tax elasticities of automobile demand.

The elasticities estimated in this study show that the demand for diesel automobiles is quite sensitive to the number of diesel vehicle imports would be cut by about 16,000 units over the next five years, leaving annual nitrogen oxide emissions 1,083 tons lower and emissions of particulate matter 106 tons lower. vehicle price and the tax differential between gasoline and diesel. This provides a basis for implementing a tax policy involving equalization of the gasoline and diesel tax rates and the introduction of a tax on diesel automobiles that would be quite effective in reducing externalities, and most particularly in reducing emissions of nitrogen oxide and particulate matter. To obtain a more precise estimate of the effects of a tax policy of this type, it would be worthwhile for future research to carry out an even more detailed disaggregation of automobile demand than this study has. It is particularly important to consider the different makes and models of automobile so that consumers' patterns of substitution between different automobiles in response to tax rises can be studied with greater accuracy.

(Original: Spanish)

Bibliography

Agostini, C. (2007), "The impact of corporate state taxes on FDI location", Public Finance Review, vol. 35, No. 3, London, Sage Publications.

Agostini, C. and I. Jalile (2009), "Efectos de los impuestos corporativos en la inversión extranjera en América Latina", Latin American Research Review, vol. 44, No. 2, Pittsburgh, Latin American Studies Association.

Agras, J. and D. Chapman (1999), "The Kyoto Protocol, CAFE standards, and gasoline taxes", Contemporary Economic Policy, vol. 17, No. 3, Huntington Beach, Western Economic Association International.

Bento, A.M. and others (2009), "Distributional and efficiency impacts of gasoline taxes", American Economic Review, vol. 99, No. 3, Nashville, Tennessee, American Economic Association.

(2005), "Distributional and efficiency impacts of increased U.S. gasoline taxes: an econometrically based multi-market study", American Economic Review, vol. 95, No. 2, Nashville, Tennessee, American Economic Association.
Berry, S. (1994), "Estimating discrete choice models of product differentiation", Rand Journal of Economics, vol. 25, No. 2, Santa Monica, California, The Rand Corporation.

Berry, S., J. Levinsohn and A. Pakes (1998), "Differentiated products demand systems from a combination of micro and macro data: the new car market", NBER Working Paper, No. 6481, Cambridge, Massachusetts, National Bureau of Economic Research.

(1995), "Automobile prices in market equilibrium", Econometrica, vol. 63, No. 4, New York, Econometric Society.

Boyd, H.J. and R.E. Mellman (1980), "The effect of fuel economy standards on the U.S. automotive market: an hedonic demand analysis", Transportation Research, vol. 14, No. 5-6, Amsterdam, Elsevier.

Cardell, N.S. and F. Dunbar (1980), "Measuring the societal impacts of automobile downsizing", Transportation Research, vol. 14, No. 5-6, Amsterdam, Elsevier.

Chow, G. (1957), The Demand for Automobiles in the United States, Amsterdam, North-Holland. 
Crawford, I. and S. Smith (1995), "Fiscal instruments for air pollution abatements in road transport", Journal of Transport Economics and Policy, vol. 29, No. 1, Bath, University of Bath.

Goldberg, P. (1995), "Product differentiation and oligopoly in international markets: the case of the U.S. automobile industry", Econometrica, vol. 63, No. 4, New York, Econometric Society.

Greene, D. (1986), "The market share of diesel cars in the USA, 1979-83”, Energy Economics, vol. 8, No. 1, Amsterdam, Elsevier.

Haughton, J. and S. Sarkar (1996), "Gasoline tax as a corrective tax: estimates for the United States, 1970-1991", The Energy Journal, vol. 17, No. 2, Cleveland, International Association for Energy Economics.

Jacobson, M. (2002), "Control of fossil-fuel particular black carbon and organic matter, possibly the most effective method of slowing global warming", Journal of Geophysical Research, vol. 107, No. 19, Washington, D.C., American Geophysical Union.

Levinsohn, J. (1996), "Empirics of taxes on differentiated products: the case of tariffs in the U.S. automobile industry", Trade Policy Issues and Empirical Analysis, R.E. Baldwin (ed.), Chicago, University of Chicago Press.

Mazzi, E. and H. Dowlatabadi (2007), "Air quality impacts of climate mitigation: UK policy and passenger vehicles choice”, Environment Science Technology, vol. 41, No. 2, Washington, D.C., American Chemical Society.

McFadden, D. (1974), "Conditional logit analysis of qualitative choice behavior", Frontiers in Econometrics, Paul Zarembka (ed.), New York, New York Academic Press.

Michaelis, L. (1995), "The abatement of air pollution from motor vehicles: the role of alternative fuels", Journal of Transport Economics and Policy, vol. 29, Bath, University of Bath.
Nevo, A. (2001), "Measuring market power in the ready-to-eat cereal industry", Econometrica, vol. 69, No. 2, New York, Econometric Society.

(2000), "Mergers with differentiated products: the case of the ready-to-eat cereal industry", Rand Journal of Economics, vol. 31, No. 3, Santa Monica, California, The Rand Corporation.

Portney, P.R. and others (2003), "The economics of fuel economy standards", Journal of Economic Perspectives, vol. 17, No. 4, Nashville, Tennessee, American Economic Association.

Suits, D. (1958), "The demand for new automobiles in the United States, 1929-1956", Review of Economics and Statistics, vol. 40, No. 3, Cambridge, Massachuetts, The MIT Press.

Tardiff, T. (1980), "Vehicle choice models: review of previous studies and directions for further research", Transportation Research, vol. 14, No. 5-6, Amsterdam, Elsevier.

Trandel, G. (1991), "The bias to omitting quality when estimating automobile demand", Review of Economics and Statistics, vol. 73, No. 3, Cambridge, Massachusetts, The MIT Press.

Thorpe, S.G. (1997), "Fuel economy standards, new vehicles sales and average fuel efficiency", Journal of Regulatory Economics, vol. 11, No. 3, Springer.

Verboven, F. (2002), "Quality-based price discrimination and tax incidence: evidence from gasoline and diesel cars", Rand Journal of Economics, vol. 33, No. 2, Santa Monica, California, The Rand Corporation.

West, S.E. and R.C. Williams (2004), "Empirical estimates for environmental policy making in a second-best setting", NBER Working Paper, No. 10330, Cambridge, Massachusetts, National Bureau of Economic Research.

Wykoff, F. (1973), "A user cost approach to new automobile purchases", Review of Economic Studies, vol. 40, No. 3, Oxford, Institute of Economics and Statistics, University of Oxford. 